\title{
Do Good Corporate Governance and Financing Risk Management Matter for Islamic Banks' Performance in Indonesia?
}

\author{
Agustina Maulidar ${ }^{1}$, M. Shabri Abdul Majid ${ }^{2 *}$ \\ *Corresponding author
}

\begin{abstract}
The purpose of this study is to examine and analyze the influence of the implementation of Good Corporate Governance principles and financing risk management on the Islamic banks' performance in Indonesia over the 2010-2019 period. 11 full-pledge Islamic Banks (BUS) was selected as the study sample using the purposive sampling technique and analyzed using the panel multiple regression techniques. The study found that Good Corporate Governance (GCG) and Financing to Deposit Ratio (FDR) positively influence the Islamic banks' performance. In contrast, Non-Performing Financing (NPF) has a negative influence on Islamic banks' performance. These findings imply that to promote the performance further, the Islamic banks should enhance the implementation of GCG principles and minimize NPF by improving financing risk management and enhance their financing by allocating their existing funds to the bankable and productive economic sectors.
\end{abstract}

Keywords: good corporate governance, financing risk management, non-performing financing, financing to deposit ratio, Islamic banks' performance

JEL Classification: G21, G34

\begin{abstract}
Abstrak. Tujuan dari penelitian ini adalah untuk menguji dan menganalisis pengaruh penerapan prinsip-prinsip tata kelola perusahaan yang baik dan manajemen risiko pembiayaan terhadap kinerja bank syariah di Indonesia selama periode 2010-2019. Sebanyak 11 Bank Umum Syariah (BUS) dipilih sebagai sampel penelitian dengan menggunakan teknik purposive sampling dan dianalisis dengan teknik regresi berganda panel. Studi ini menemukan bahwa tata kelola perusahaan yang baik dan rasio pembiayaan terhadap deposit memiliki pengaruh signifikan positif terhadap kinerja bank syariah, sementara pembiayaan bermasalah ditemukan memiliki pengaruh signifikan negatif terhadap kinerja bank syariah. Temuan ini menyiratkan bahwa untuk lebih meningkatkan kinerja, bank syariah harus meningkatkan penerapan prinsip-prinsip tata kelola perusahaan yang baik dan meminimalkan pembiayaan bermasalah dengan meningkatkan manajemen risiko pembiayaan dan mengalokasikan pembiayaan mereka ke sektor ekonomi yang produktif.
\end{abstract}

Kata Kunci: tata kelola perusahaan yang baik, manajemen risiko pembiayaan, pembiayaan bermasalah, rasio pembiayaan terhadap deposito, kinerja bank syariah

\section{How to Cite:}

Maulidar, A., \& Majid, M. S. A. (2020). Do Good Corporate Governance and Financing Risk Management Matter for Islamic Banks' Performance in Indonesia?. Etikonomi: Jurnal Ekonomi, 19(2), 169 - 184. https://doi.org/10.15408/ etk.v19i2.15080. 


\section{Introduction}

The establishment of the Islamic Development Bank (IDB) in Jeddah in December 1973 became one of the triggers for various banks with Islamic principles. IDB was inaugurated in July 1975 and began operations in October 1975. According to Yaya et al. (2016), IDB is an international financial institution founded on the declaration of the results of conferences of Ministers of Finance of Muslim countries, intending to support the progress of economic and social development of member countries and other Muslim communities based on the Islamic principles. According to Rivai \& Usman (2012), another trigger of Islamic banks' presence was the gathering of the world's Islamic economists for the first time in 1976 in the International Conference on Islamic Economics and Finance in Jeddah.

Because of these triggers, in the 1970s, several Islamic banks began to emerge. In the Middle East, Dubai Islamic Bank establish in 1975, the Faisal Islamic Bank of Sudan and the Faisal Islamic Bank of Egypt launched in 1977, and the Bahrain Islamic Bank was established in 1979. In the Asia-Pacific region, the Muslim Pilgrims Savings Corporation (Tabung Haji), which aims to help Malaysians who desire to make savings to perform the Hajj, was established in 1962 (Suryani, 2012).

Subsequently, in Indonesia, Bank Muamalat Indonesia (BMI) was established in 1992 as the first Islamic bank, following other banks. When the crisis hit Indonesia in 1998, BMI was the only bank that was not shaken by the crisis, while almost all other banks and conventional financial institutions had to face bankruptcy. After experiencing Islamic banks' ability to survive during the crisis, Bank Indonesia (BI), the central bank of Indonesia, is committed to developing Islamic banking in Indonesia. One proof of BI's commitment is the National Sharia Banking Development Blueprint for the period 2002-2011.

According to Soemitra (2009), the Indonesian Islamic banking development blueprint published by BI contains the vision, mission, and objectives of developing Islamic banking and a set of strategic initiatives with clear priorities in answering the main challenges and achieving the goals over the next ten year. With the Islamic banking development blueprint's issuance, the Islamic banking market is also increasingly widespread and competitive.

The development of Islamic banking in Indonesia is also the result of the Indonesian people's demands who need an alternative banking system (Hamid et al., 2017). The intended alternative is where banks can provide healthy banking or financial services and meet Islamic principles. Seeing the magnitude of this request, then a particular constitution on Islamic Banking, namely Islamic Bank Regulation No. 21 of 2008, was present as the legalization of Islamic banking activities that strengthened Islamic banks' foundation in Indonesia (Bank Indonesia, 2002).

Consistently over time, Islamic banks in Indonesia have shown their development. As illustrated in Table 1, the total assets of Islamic banks to the banking industry's total assets have increased from $3.24 \%$ in 2010 to $4.89 \%$ in 2013 . Although the values had slightly decreased to $4.83 \%$ in 2015 , they showed a steady increase afterward and achieved $5.74 \%$ in 2017. After the conversions of Bank Aceh into full-fledged Islamic banking in 2016 and Bank Nusa Tenggara Barat (NTB) in 2018, the market share of Islamic banking institutions 
nationwide jumped to $5.91 \%$. In 2019, the market share of Islamic banks in Indonesia reached 6.12\% (Financial Services Authority, Indonesia, 2020).

Table 1. Islamic Banking Market Share in Indonesia, 2009-2019

\begin{tabular}{cccc}
\hline Period & $\begin{array}{c}\text { Islamic Banking } \\
\text { Total Aset (IDR Billion) }\end{array}$ & $\begin{array}{c}\text { Islamic Banking Market } \\
\text { Share (\%) }\end{array}$ & $\begin{array}{c}\text { Public Commercial Banks' Total } \\
\text { Assets (IDR Billion) }\end{array}$ \\
\hline 2010 & 97.5 & 3.24 & $3,008.8$ \\
2011 & 145.5 & 3.98 & $3,652.8$ \\
2012 & 195.1 & 4.57 & $4,262.6$ \\
2013 & 242.3 & 4.89 & $4,954.5$ \\
2014 & 272.3 & 4.85 & $5,615.1$ \\
2015 & 296.3 & 4.83 & $6,132.6$ \\
2016 & 356.5 & 5.29 & $6,729.8$ \\
2017 & 424.2 & 5.74 & $7,387.1$ \\
2018 & 477.3 & 5.91 & $8,068.3$ \\
2019 & 524.6 & 6.12 & $8,562.9$ \\
\hline
\end{tabular}

Source: The Banking Statistics and the Sharia Banking Statistics, Financial Services Authority, Indonesia (2010 - 2020).

The development of Islamic banks is also marked by an increase in the number of Islamic banks. Karim (2013) states that in 2005 the number of Islamic banks in Indonesia amounted to 20 units divided into 3 Sharia Commercial Banks and 17 Sharia Business Units. Meanwhile, the numbers of Sharia Rural Banks were 88 units. In the period of nine years from 2009 to December 2017, the number of banks increased and followed by the development of the Islamic banking office network. As illustrated in Table 2, in 2019, there were 14 Sharia Commercial Banks with 1,919 units of offices, 20 Sharia Business Units with a total of 381 offices, and 164 Sharia Rural Banks with a total of 617 offices (The Sharia Banking Statistics, the Financial Services Authority, Indonesia, 2020).

The rapid development of the banks is not isolated from their excellent performances. According to Mewengkang (2013), performance shows how a bank can produce a good achievement. Performance reflects the company's ability to allocate and manage its resources. As one of the financial institutions that offer Islamic financial services to the public, Islamic banks should be able to maintain or even improve their performance so that they can compete and survive amidst the fierce competition within the banking industry (Majid et al., 2014; and Hamid et al., 2017). Besides, with the increasing number of Islamic banks in Indonesia, customers think critically and selectively in choosing the best bank to save their funds. Especially at this time, customers have not only been using bank services to deposit funds, but they have also perceived the banks as avenues for investing funds with the hope of obtaining profits in the future (Hidayati \& Utiyati, 2013). Therefore, Islamic banks with high-performance levels will be looked at and become the main target of customers to invest their funds. In this case, profit or profitability can be a measure to see the bank's achievements in its operations. 
Agustina Maulidar. Do Good Corporate Governance and Financing Risk Management

Table 2. Number of Sharia Banks and Sharia Banking Office Networks in Indonesia

\begin{tabular}{|c|c|c|c|c|c|c|c|c|c|c|c|}
\hline Bank/Period & 2009 & 2010 & 2011 & 2012 & 2013 & 2014 & 2015 & 2016 & 2017 & 2018 & 2019 \\
\hline \multicolumn{12}{|c|}{ Sharia Commercial Bank: } \\
\hline Number of Bank & 6 & 11 & 11 & 11 & 11 & 12 & 12 & 13 & 13 & 14 & 14 \\
\hline Number of Offices & 711 & 1,215 & 1,401 & 1,745 & 1,998 & 2,163 & 1,990 & 1,869 & 1,825 & 1,875 & 1,919 \\
\hline \multicolumn{12}{|c|}{ Sharia Business Unit: } \\
\hline Number of Bank & 25 & 23 & 24 & 24 & 23 & 22 & 22 & 21 & 21 & 21 & 20 \\
\hline Number of Offices & 287 & 262 & 336 & 517 & 590 & 320 & 311 & 332 & 344 & 354 & 381 \\
\hline \multicolumn{12}{|l|}{ Sharia Rural Bank: } \\
\hline Number of Bank & 138 & 150 & 155 & 158 & 163 & 163 & 163 & 166 & 167 & 167 & 164 \\
\hline Number of Offices & 225 & 286 & 364 & 401 & 402 & 439 & 446 & 453 & 441 & 495 & 617 \\
\hline
\end{tabular}

Source: Sharia Banking Statistics, Financial Services Authority, Indonesia (2009 - 2020)

From the perspective of shareholders, profitability can use as a benchmark for how much profit can gain if they invest in the company. Meanwhile, for managers, profitability can be used to determine the success of the company that they lead. If a company's profitability is high, proving that the company has been efficient in carrying out its operational activities, this also shows that the company has great potential in generating profits (Handayani et al., 2016).

According to Marchyta \& Astuti (2015), in measuring the performance of a company, two profitability ratios are commonly used, namely Returns on Assets (ROA) and Returns on Equity (ROE). ROA is an indicator used to measure how much company profits are based on its total Asset, while ROA illustrates how management is efficient in managing its assets to generate income (Ahmed et al., 2017). If the ROA value of a bank is large, then the bank's profit will also be extensive, and the bank's position will be better in terms of asset use. According to Veno \& Syamsudin (2016), ROE is one of the profitability ratios that show the ability of a company to generate net income for the return of shareholders' equity. In other words, ROE is a financial ratio used to measure how much the level of profitability of equity. If a company has a considerable ROE value, this indicates that its performance is good.

Although Islamic banks are new players compared to conventional banks, Islamic banks have proven to adequately use and well-managed their capital and Asset for the last decade. The fact is, first, based on a report from the Financial Services Authority of Indonesia in December 2017, the banks' assets management, as measured by ROA, reached $2.55 \%$. Second, for capital use activities, the banks produced $19.40 \%$ level of returns within the same period, as shown by the ROE ratio.

The fluctuations of the values of ROA and ROE have witnessed the changes in Islamic banks' performance, caused by the market competition between Islamic banks and conventional banks. In winning competition amidst the rapid growth of banking, Islamic banks need to enhance Good Corporate Governance (GCG). The presence of 
corporate governance for Islamic banks ensures the Shariah compliance of all Islamic banking operations. Thus, the implementation of GCG is essential for Islamic banks to better position themselves in Indonesia's parallel banking system, where both Islamic and conventional banks co-exist in the banking industry. This difference is sought by customers who want a bank with Sharia principles, making Islamic banks superior and having their markets. It also urges Islamic banks to be able to carry out financing management properly. Therefore, the application of GCG and financing risk management in Islamic banking is becoming increasingly important, as these factors play essential roles in improving the performance of Islamic banks, which is one of the main factors in attracting public interest and trust.

Due to the importance of the implementation of GCG, the Central Bank of Indonesia, Bank Indonesia issued Bank Indonesia Regulation in 2006, concerning the GCG for both conventional and Sharia commercial banks. To further enhance the implementation of GCG, in 2009, Bank Indonesia has issued Bank Indonesia Regulation, concerning the implementation of GCG for both full-fledged and Islamic window of Sharia banks in Indonesia. According to Desiana et al. (2016), the implementation of GCG is a vital aspect for the Islamic banks to improve the company's performance by monitoring its management's performance and ensuring management accountability to shareholders. The proxy used to measure GCG is the composite value of GCG self-assessment. GCG self-assessment is an assessment of the implementation of GCG principles conducted by the bank following the eleven factors that have been determined by the Bank of Indonesia.

Apart from the implementation of GCG to improve performance, Islamic banks should also pay their attention to financing risk management aspects. In the external and internal conditions of Islamic banks that are experiencing relatively rapid development and accompanied by the increasing risk of banking business activities, Islamic banks are in dire need to implement prudent risk management. A risk is an event where a measure of uncertainty arises that can cause losses. As a financial institution, banks can face a variety of risks, including market risk (changes in net asset value due to changes in economic factors), credit/financing risk (changes in net asset value due to changes in the ability of third parties to fulfill their obligations), operational risk (costs arising from errors in making transactions), and performance risks (failure to monitor employees or failure in using measurement methods) (Prabowo, 2009). Because it has various potential risks, as Prabowo (2009) mentioned, risk management in the banking industry has become an essential part of the operationalization of risks faced by banks. In minimizing risk, the risk management process includes risk identification, risk measurement, risk management, risk limitation, and risk monitoring.

One risk that becomes a concentration of Islamic banks is the risk of financing. The risk of financing is a risk that causes losses to occur due to the possibility that the counterparty will fail to fulfill its obligations, or it can be said that it will not pay back the financing. One indicator that can be used to measure the risk of financing in Islamic banks is NonPerforming Financing (NPF) (Ekaputri, 2014). NPF is related to the risk of financing provided by banks, and it shows the ability of bank management to manage non-performing 
financing provided by banks to customers (Maesun \& Purwaji, 2016). Therefore, GCG and financing risk management are essential in managing banking institutions that have been created and designed to improve bank performance, protect the interests of stakeholders, and improve their compliance with laws and ethical values that generally applicable.

Previous studies have investigated the effects of GCG (Sumarsono, 2014; Kartika, 2014; and Fauzi, 2016) and financial risk management (Ekaputri, 2014; Siswanti, 2016; and Budiman, 2016) on companies' performance in Indonesia. For example, Sumarsono (2014) examined the effect of GCG implementation on the profitability of publicly listed companies listed on the Indonesian Stock Exchange. Kartika (2014) and Fauzi (2016) examined the effect of GCG implementation on full-fledged Sharia banking in Indonesia. They measure the implementation of GCG through indicators of the Sharia supervisory board, the board of commissioners, the board of directors, and the audit committee on Islamic banks' performance, measured by ROA. Similarly, Desiana et al. (2016) investigated the effect of GCG on profitability, measured by ROE, on Sharia banks in Indonesia for 2010-2015. Overall, these studies found the important role of GCG on the firms' performance, and only a few of the found the insignificant effect of GCG on banking performance (Fauzi, 2016).

On the other hand, Ekaputri (2014), Siswanti (2016), and Budiman (2016) examined the effects of financing risk management represented by the NPF on Islamic banks Indonesia. These studies found mixed findings; some recorded the significant negative effect of NPF on banking performance (Ekaputri, 2014; and Budiman, 2016), and few studies documented the significant positive effect of the NPF on the performance of Sharia banking institution (Siswanti, 2016). These reviewed studies documented mixed findings of GCG and financial risk management's effects on firms' performance. These shreds of evidence could be partially due to their studies investigating the effects of GCG and management risk separately on the banking performance, different variables' measurement, the various period of the study, and different use of data analysis techniques. Thus, to provide more robust and latest findings, this study purposely explores the effect of both GCG and financial risk management on the Sharia banking institution using panel data regression analysis over the period 2010-2019.

This study's findings are hoped to sheds some light on Sharia banking management to design proper strategies to implement GCG and financial management risk improving the banking performance. This study's findings are also crucial for the relevant governmental authorities, such as the Financial Services Authority and Bank Indonesia, to promote the Sharia banking industry's existence by enhancing their performance through the implementation of GCG and management risk. Sharia banks' customers also hoped to gain some vital information to predict the banks' performance based on GCG and management risk policies implemented by the banks.

The rest of the study is structured in the following manner. Section 2 provides the research method on which the data analyses are based. Section 3 presents the findings and their discussion, followed by the concluding remarks in the final section, Section 4 . 


\section{Methods}

This study empirically explores the relationship between the implementation of Good Corporate Governance (GCG) and financing risk management on the performance of 11 full-fledged Islamic commercial banks in Indonesia over the period from 2010 to 2018. Of 13 existing Islamic banks during the study period, 11 were selected using the purposive sampling technique. The selected banks are based on the following criteria: full-fledged Islamic banks that regularly publish annual reports and GCG implementation reports.

Since the study investigates 13 cross-sectional banks over nine years of time series period, the panel regression method is used to answer the study's objective. Commonly, the panel regression analysis comprises three models, namely: Common Effect Model (CEM)/ Pooled Ordinary Least Square (POLS), Fixed Effect Model (FEM)/Least Squares Dummy Variable (LSDV) technique, and Random Effect Model (REM)/Error Components Model (ECM).

Sunarwan (2015) defines the Pooled Ordinary Least Square (POLS) model as the simplest estimation method of the panel data regression model with an intercept assumption and constant slope coefficient between time and cross-section (common effect). This model is also called the Common Effect Model (CEM), does not pay attention to individual dimensions or time. It is assumed that the data behavior between companies is the same in various periods. The form of the model is:

$$
P R F_{i t}=\beta_{1}+\beta_{2} G C G X_{2 i t}+\beta_{3} N P F_{3 i t}+\beta_{4} F D R_{4 i t}+\varepsilon_{i t}
$$

Meanwhile, the Fixed Effects Model (FEM) assumes that individuals' differences can accommodate the difference in intercepts. To estimate the fixed effects panel data using a dummy variable technique to capture the intercept differences between variables. This estimation model is often called the Least Squares Dummy Variable (LSDV) technique (Sally, 2015). Gujarati (2009) defines the meaning of the term fixed effects, although the intercept may differ between individuals, the intercept of each individual does not vary from time to time that is invariant time. Using dummy variables can allow intercepts to vary between individuals, specifically, differential intercept dummies. Therefore, the equation is as follows:

$$
P R F_{i t}=\alpha_{1}+\alpha_{2} D_{2 i}+\alpha_{3} D_{3 i}+\alpha_{4} D_{4 i}+\beta_{2} G C G_{2 i t}+\beta_{3} N P F_{3 i t}+\beta_{4} F D R_{4 i t}+\varepsilon_{i t}
$$

Although the FEM or LSDV is easy to implement, Gujarati (2009) states that the LSDV model's reason is that dummy variables can represent a lack of knowledge about the model. However, LSDV can result in the loss of a significant number of degrees of freedom. Therefore, the Error Components Model (ECM) or the Random Effects Model (REM) can overcome this problem. The Generalized Least Squares (GLS) method can estimate disturbance variables that correlate between individuals and years (Majid \& Maulana, 2012; Arfan et al., 2017; Majid et al., 2020). If we do not take into account this correlation structure, the resulting estimator will be inefficient. The REM equation can write as follows: 
$P R F_{i t}=\beta_{1 i}+\beta_{2} G C G_{2 i t}+\beta_{3} N P F_{3 i t}+\beta_{4} F D R_{4 i t}+\mu_{i t}$

Where PRF is the performance of the Islamic banks; $G C G$ is the good corporate governance; $N P F$ is the non-performing financing; $F D R$ is the financing deposit ratio; $\beta_{1}$ and $\alpha_{1}$ are the constant terms, $\beta_{2}, \beta_{3}$ and $\beta_{4}$ are the estimated of independent variables, $D$ is the dummy variable, $\alpha_{2} \alpha_{3}$ and $\alpha_{4}$ are the estimated of dummy variables, $\varepsilon$ and $\mu$ are the error terms, $i$ and $t$ are the Islamic bank $i$ and period $t$.

The data used in this study are financial ratios of profitability measured by Returns on Assets (ROA), Good Corporate Government (GCG) measured by 11 indicators proposed by Bank of Indonesia, and financial risk management measured by the Non-Performing Financing (NPF) and Financing Deposit Ratio (FDR). Secondary data from 2010-2018 gathered from the Islamic banks' financial reports and Sharia Statistics, Financial Services Authority of Indonesia.

The year 2010 is taken as a starting data period for data analysis, since starting from the year 2010 onwards, all full-fledged Islamic banks and Islamic windows have been mandatory to implement the GCG principles. The selected data period is in line with the Circular of Bank Indonesia No. 12/13/DPbS and Bank Indonesia Regulation No.11/33/PBI/2009 that obliged all Sharia commercial banks and sharia business units to implement GCG principles in their operations.

\section{Result and Discussion}

This study adopted the panel data analysis method. The panel data has three models, namely Common Effect Model (CEM)/Pooled Ordinary Least Square (POLS), Fixed Effect Model (FEM)/Least Squares Dummy Variable (LSDV) technique, and Random Effect Model (REM)/Error Components Model (ECM). In selecting the most appropriate panel regression model for data analysis, the study conducts the Chow test, the Hausman test, and the Lagrange Multiplier test.

The Chow test was conducted to determine whether the most appropriate panel data model between the CEM/POLS method or by the FEM method (Sobita et al., 2014). If the test results show that the most appropriate model to be used is the CEM/POLS, the Hausman test is no longer needed to perform. However, if the Chow test results show otherwise, the FEM model is the most suitable model to be used; thus, the Hausman test needs to be further conducted. The Chow Test results in this study can show in Table 3.

Referring to the Chow test results from Table 3, the study failed to reject $\mathrm{H}_{0}$ (CEM/ PLS), as shown by the insignificant value of cross-section F $(0.285>0.10)$. This finding means that the CEM/POLS is the most appropriate model to be adopted compared to the FEM. Since the study rejected the FEM, the Lagrange Multiplier test needs to be further tested to determine which panel regression model should be selected as the best model between CEM/POLS and REM/ECM (Umar, 2014). Table 3 illustrated that the probability value of Breusch Pagan is found to be insignificant $(0.1793>0.10)$, showing a non-rejection of $\mathrm{H}_{0}$ (CEM/POLS), while the rejection of $\mathrm{H}_{1}$ (REM/ECM). These findings show that both based on the Chow test and Lagrange Multiplier test, the CEM/POLS is found to be the most 
appropriate model to be adopted in the study. Having identified the CEM/POLS model is the most suitable panel regression model to be estimated in our study, in the next step, the study estimates the model where their findings show in Table 4.

Table 3. Tests of Panel Model Selection

\begin{tabular}{lccc}
\hline \multicolumn{1}{c}{ Chow Test: Effects Test } & Statistic & d.f. & Prob. \\
\hline Cross-section F & 1.238 & $(10,63)$ & 0.285 \\
Cross-section Chi-square & 13.817 & 10 & 0.181 \\
\hline Lagrange Multiplier Test & Cross-section & Time & Both \\
\hline Breusch-Pagan & 0.044 & 1.759 & 1.803 \\
Prob. & 0.832 & 0.184 & 0.179 \\
\hline
\end{tabular}

The t-test is used to see the significance of the influence of independent variables individually on the dependent variable, assuming other independent variables are constant. Positive $(+)$ and negative (-) signs indicate the direction of the relationship, whether the change in the dependent variable is in the same direction (positive) with the change in the independent variable or the opposite direction (negative). If rejecting $\mathrm{H}_{0}$ and accepting $\mathrm{H}_{1}$ means that the independent variables statistically significantly influence the dependent variable. However, if receiving $\mathrm{H}_{0}$ and rejecting $\mathrm{H}_{1}$ means that the independent variables statistically do not significantly affect the dependent variable.

Table 4. Findings of the Panel Regression Model

\begin{tabular}{|c|c|c|c|c|}
\hline Variable & Coefficient & Std. Error & t-Statistic & Prob. \\
\hline GCG & $1.442^{*}$ & 0.759 & 1.900 & 0.061 \\
\hline NPF & $-0.404^{* * *}$ & 0.031 & -12.822 & 0.000 \\
\hline \multirow[t]{2}{*}{ FDR } & $0.014^{* * *}$ & 0.004 & 3.123 & 0.002 \\
\hline & $\begin{aligned} R^{2}= & 0.70 \\
& \text { Prob. }\end{aligned}$ & $\begin{array}{l}=0.694 ; F-s \\
0 ; \text { Durbin-V }\end{array}$ & $\begin{array}{l}.087^{* * * *} ; \\
3 .\end{array}$ & \\
\hline
\end{tabular}

Note: ${ }^{* * *}$ and ${ }^{*}$ indicate significant at the $1 \%$ and $10 \%$ levels, respectively.

As illustrated in Table 4, the study found a significant positive effect of GCG on bank performance, measured by ROA at the $10 \%$ level of significance with the estimated value of 1.442. Specifically, this shows that a $100 \%$ increase in the implementation of GCG principles has increased banking performance by $14.42 \%$. This finding shows that the first hypothesis, $\mathrm{H}_{1}$, is not rejected, implying that the GCG variable has a significant partial effect on Islamic banks' performance in Indonesia. This finding provided evidence of the importance of GCG implementation for the promotion of Islamic banking performance.

GCG is one crucial part of the process and structure used by the Islamic banking organs such as shareholders, capital owners, commissioners, Shariah supervisory boards, and directors to improve business success and accountability. Its GCG's principles could also be used as a guide to maximize shareholder value in the long term while taking into account the 
interests of other stakeholders, based on decision-making regulations and ethical values. The results of our study show the significance of GCG in affecting banking performance. This finding further implies that to enhance Islamic banking performance in the future, the banks should pay more attention to improve the application of GCG principles based on Islamic values.

The result of this study is in line with previous research conducted by Fauzi (2016), Desiana et al. (2016), and Tumewu \& Alexander (2014), which state that GCG has a positive impact on the performance of Islamic banks. Kusuma \& Ayumardani (2016) also found that corporate governance efficiency improved Islamic banks' performance in Indonesia over the 2010-2014 period. Kusuma \& Rosadi (2019) and Irawati et al. (2019) also provided pieces of evidence on the importance of good governance in improving Islamic banking performances in Indonesia. However, this research contradicts the results of previous research conducted by Syam \& Najda (2012), which states that the implementation of GCG does not significantly influence Islamic banks' profitability.

Table 4 also provides findings of the second hypothesis test, $\mathrm{H}_{2}$ - Non-Performing Financing (NPF) affects Islamic banking performance. The study found a significant negative effect of NPF on banking performance at the $1 \%$ significance level with the estimated value of -0.404 . This finding shows a non-rejection of the second hypothesis, $\mathrm{H}_{2}$. This finding shows that an increase in NPF by $100 \%$ has caused a $40.4 \%$ decline in banking performance. An increase in NPF has affected the bank's performance inversely because the higher the NPF, the worse the quality of bank financing that has the potential of problematic financing to be greater, affecting the fall in the value of ROA.

NPF measures the amount of financing that is problematic and may not be invoiced. The result of our study indicated a significant negative effect of NPF on banking performance. The greater the value of the NPF, the worse would be the Islamic bank's performance due to the presence of problematic financing reflected in the NPF. In turn, this could result in the banks' loss of opportunity to obtain income from the financing provided, thus worsening their profitability. This finding implies that, in the future, Islamic banks should pay more attention and be careful when providing financing not to increase NPF and, consequently, deteriorate the performance of Islamic banks.

The results of this study support the findings of previous studies conducted by Ferdyant \& Takidah (2014), Yuliany (2014), and Sulistianingrum (2013). They recorded a negative impact of NPF on performance, as measured by ROA. Fakhrunnas \& Imron (2019) documented a negative influence of NPF on 21 rural Islamic banks' performance across 21 in Indonesia during the 2013-2017 periods. Similarly, Sanusi \& Zulaikha (2019) found evidence that NPF negatively affected Islamic rural banks' profitability in Indonesia. Finally, Zaman \& Chowdhury (2019) also found a negative correlation between NPF and Islamic banking performance in Bangladesh.

The finding of the third hypothesis, $\mathrm{H}_{3}$ - the financing to deposit ratio, affects the banking performance, and is also reported in Table 4. The Financing to Deposit Ratio (FDR) has a positive effect on banking performance at the $1 \%$ level of significance value 
with the estimated value of 0.014 , confirming the non-rejection of the third hypothesis, $\mathrm{H}_{3}$. Specifically, this finding shows an increase of $100 \%$ in the FDR; it has caused an increase of $1.4 \%$ in banking performance. This finding also indicates the importance of managing financing to the ratio of the deposit to promoting Islamic banking performance.

Since the FDR measures the banks' financing as a source of liquidity, which is by dividing the amount of financing provided by banks against the third party funds, the higher the FDR implies the higher ability of Islamic banks to channel their funds to finance the third party. FDR has a positive impact on the banking performance caused by the banks' higher ability to utilize their funds channeled to the third party optimally. With the distribution of large third party funds, the banks earned higher returns on their assets as a measure of banking performance. This further implies that Islamic banking institutions should continue to pay attention to financing management so that Islamic banks' performance will be steadily improving in the future.

This finding is in harmony with previous research conducted by Sulistianingrum (2013), which states that FDR has a positive and significant effect on performance measured by ROA. Apip et al. (2019) shared a similar finding of FDR's significant positive effect on Islamic banking performance in Indonesia. In the long run, the FDR is found to positively affect the performance of 11 Islamic banks in Indonesia over the period from 2014 to 2018 (Aspirantia et al., 2019). However, this research contradicts the research results conducted by Suryani (2012), which states that FDR does not affect performance.

Finally, our estimated model is free from model misspecification, as indicated by the F-statistics's significance at the $1 \%$ level of significance. This finding shows the model's power to predict banking performance, considering GCG, NPF, and FDR as their determinants. As shown by the determination of adjusted $\mathrm{R}^{2}$, the estimated coefficient of 0.694 shows that $69.4 \%$ variations in the Islamic banking performance predict by the changes in GCG, NPF, and FDR variables. On the other hand, only 30.6\% of Islamic banking performance variations explain by other variables such as capital adequacy, assets management, dividend policy, and other factors that not include in the model.

\section{Conclusion}

This study empirically measured and analyzed the influence of the implementation of Good Corporate Governance (GCG) and financing risk Management on Islamic banking performance in Indonesia over the 2010 to 2018 period. Based on the panel regression of Common Effect Model/Pooled Least Square, the study found the positive effects of GCG on Financing to Deposits Ratio (FDR) on the Islamic banking performance. Meanwhile, Non-Performing Financing (NPF) has a negative impact on Islamic banks' performance. These findings imply that to promote Islamic banking performance further, the managers should enhance the implementation of the GCG principles and financing risk management by channeling financing to credible and bankable productive economic sectors.

Future studies on this topic could provide reliable and comprehensive empirical by incorporating Islamic banking performance determinants into the model of analysis. These 
determinants could include both internal and external determinants contributing to Islamic banking performances. Finally, incorporating more Islamic banks across the globe into the study and analyzing them will comparatively enrich empirical findings.

\section{References}

Ahmed, S., Jannat, R., \& Ahmed, S. U. (2017). Corporate Governance Practices in the Banking Sector of Bangladesh: Do They Really Matter?. Banks and Bank Systems, 12(1), 27-35.

Apip, M., Prawiranegara, B., Herlina, E., \& Rudiana, I. F. (2019). Bank Health Ratio, The Profitability and CSR Disclosure in Indonesia Islamic Bank. In Proceeding of Medan International Conference Economics and Business Applied, 1(1), 7-7.

Arfan, M., Basri, H., Handayani, R., Majid, M.S.A., Fahlevi, H., \& Dianah, A. (2017). Determinants of Cash Holding of Listed Manufacturing Companies in The Indonesian Stock Exchange. DLSU Business and Economics Review, 26(2), 1-12.

Aspirantia, T., Hadi, A. R. A., Amaliah, I., \& Mafruhat, A. Y. (2019). Non-performing Financing and Asset Quality: Evidence from Indonesian Islamic Banks. International Journal of Innovation, Creativity and Change, 10(6), 1-23.

Bank Indonesia. (2002). Cetak Biru Pengembangan Perbankan Syariah Indonesia (The Blue print of Indonesian Islamic Banking Development). Jakarta: Bank Indonesia.

Budiman, F. (2016). Pengaruh Kualitas Penerapan Good Corporate Governance (GCG) Terhadap Tingkat Pengembalian dan Risiko Pembiayaan Bank Syariah di Indonesia (The Effect of the Quality of the Implementation of Good Corporate Governance (GCG) on the Rate of Return and Risk of Islamic Bank Financing in Indonesia). Muqtasid: Jurnal Ekonomi dan Perbankan Syariah, 7(2), 1-21.

Desiana, L., Mawardi., \& Sellya, G. (2016). Pengaruh Good Corporate Governance Terhadap Profitabilitas (ROE) pada Bank Umum Syariah di Indonesia periode 2010-2015 (Effect of Good Corporate Governance on Profitability (ROE) in Islamic Commercial Banks in Indonesia 2010-2015). I-Finance, 2(2), 1-20.

Ekaputri, C. (2014). Tata Kelola, Kinerja Rentabilitas, dan Risiko Pembiayaan Perbankan Syariah (Governance, Profitability Performance, and Financing Risk of Islamic Banking). Journal of Business and Banking, 4(1), 91-104.

Fakhrunnas, F., \& Imron, M. A. (2019). Assessing Financial Risk and Regional Macroeconomic Influence to Islamic Rural Bank Performance. Global Review of Islamic Economics and Business, 7(1), 49-55.

Fauzi, A. C. (2016). Pengaruh Good Corporate Governance Terhadap Kinerja Keuangan: Studi pada Bank Umum Syariah Indonesia tahun 2011-2015 (The Effect of Good Corporate Governance on Financial Performance: A Study on Indonesian Sharia Commercial Banks, 2011-2015). (Unpublished Thesis). Institut Agama Islam Negeri Surakarta.

Ferdyant, F., \& Takidah, E. (2014). Pengaruh Kualitas Penerapan Good Corporate Governance dan Risiko Pembiayaan Terhadap Profitabilitas Perbankan Syariah (The 
Effect of Quality of Good Corporate Governance Implementation and Financing Risk on the Profitability of Islamic Banking). Jurnal Dinamika Akuntansi dan Bisnis, 1(2), 134-149.

Financial Services Authority. (2020). The Banking Statistics and the Sharia Banking Statistics. Jakarta: OJK.

Gujarati, D. N. (2009). Basic Econometrics. Tata McGraw-Hill Education.

Hamid, A., Majid, M. S. A., \& Khairunnisah, L. (2017). An Empirical Re-examination of the Islamic Banking Performance in Indonesia. International Journal of Academic Research in Economics and Management Sciences, 6(2), 219-232.

Handayani, T., Kristianto, D., \& Astuti, D. S. P. (2016). Pengaruh Perputaran Modal Kerja, Perputaran Piutang dan Perputaran Kas terhadap Profitabilitas Perusahaan: Survei pada Perusahaan Properti dan Real Estate yang Terdaftar di Bursa Efek Indonesia Periode 2012-2014 (Effect of Turnover of Working Capital, Turnover of Accounts Receivable and Cash Turnover on Company Profitability: A Survey of Property and Real Estate Companies Listed on the Indonesia Stock Exchange 2012-2014 Period). Jurnal Akuntansi dan Sistem Teknologi Informasi, 12(2), 259-265.

Hidayati, N., \& Utiyati, S. (2013). Analisis Kinerja Keuangan antara PT. Bank Negara Indonesia (Persero) Tbk dan PT. Bank Internasional Indonesia, Tbk di Bursa Efek Indonesia (Financial Performance Analysis between PT. Bank Negara Indonesia Tbk and PT. Bank Internasional Indonesia, Tbk on the Indonesia Stock Exchange). Jurnal Ilmu \& Riset Manajemen, 2(2),1-15.

Irawati, N., Maksum, A., Sadalia, I., \& Muda, I. (2019). Financial Performance of Indonesian's Banking Industry: The Role of Good Corporate Governance, Capital Adequacy Ratio, Non-Performing Loan and Size. International Journal of Scientific and Technology Research, 8(4), 22-26.

Karim, A. (2013). Bank Islam: Analisis Fiqih dan Keuangan (Islamic Bank: Fiqh and Financial Analysis). Jakarta: PT Raja Grafindo Persada.

Kartika, I. (2014). Pengaruh Penerapan Good Corporate Governance oleh Dewan Komisaris, Dewan Direksi, Komite-komite dan Dewan Pengawas Syariah Terhadap Kinerja Perbankan Pada Bank Umum Syariah di Indonesia Tahun 2010-2013 (Pengaruh Penerapan Good Corporate Governance oleh Dewan Komisaris, Dewan Direksi, Komite-komite dan Dewan Pengawas Syariah Terhadap Kinerja Perbankan Pada Bank Umum Syariah di Indonesia Tahun 2010-2013 (The Effect of the Implementation of Good Corporate Governance by the Board of Commissioners, Board of Directors, Committees and Sharia Supervisory Board on Banking Performance in Islamic Commercial Banks in Indonesia 2010-2013). (Unpublished Thesis). Universitas Islam Negeri Syarif Hidayatullah Jakarta.

Kusuma, H., \& Ayumardani, A. (2016). The Corporate Governance Efficiency and Islamic Bank Performance: Indonesian Evidence. Polish Journal of Management Studies, 13(1), 111-120. 
Kusuma, M., \& Rosadi, S. (2019). Islamic Corporate Governance and Islamic Banking Financial Performance. Journal of Finance and Islamic Banking, 1(2), 164-179.

Maesun, E., \& Purwaji, A. (2016). Pengaruh Bagi Hasil dan Non Performing Financing (NPF) Terhadap Total Pembiayaan Bagi Hasil: Studi di Bank BNI Syariah periode 2010-2015 (The Effect of Profit Sharing and Non-Performing Financing (NPF) on Total Profit Sharing Financing: A study at Bank of BNI Sharia Period 2010-2015). E-Journal Politeknik Negeri Jakarta, 438-445.

Majid, M. S. A., \& Maulana, H. (2012). A Comparative Analysis of The Productivity of Islamic and Conventional Mutual Funds in Indonesia: Data Envelopment Analysis (DEA) and General Least Square (GLS) Approaches. Gadjah Mada International Journal of Business, 14(2), 183-208.

Majid, M. S. A., Azhari, A., Faisal, F., \& Fahlevi, H. (2020). Do Capital and Business Volume Matter for Productivity of The Cooperatives in Indonesia?. Binus Business Review, 11(1), 1-8.

Majid, M. S. A., Musnadi, S., \& Putra, I. Y. (2014). A Comparative Analysis of the Quality of Islamic and Conventional Banks' Asset Management in Indonesia. Gadjah Mada International Journal of Business, 16(2), 185-200.

Marchyta, N. K., \& Astuti, D. (2015). Pengaruh Struktur Modal dan Karakteristik Perusahaan Terhadap Profitabilitas dan Nilai Perusahaan (The Effect of Capital Structure and Company Characteristics on Profitability and Firm Value). Finesta, 3(1), 13-18.

Mewengkang, Y. R. (2013). Analisis Perbandingan Kinerja Keuangan Bank Pemerintah dan Bank Umum Swasta Nasional yang Tercatat di BEI (Comparative Analysis of the Financial Performance of Government Banks and National Private Commercial Banks Listed on the IDX). Jurnal EMBA: Jurnal Riset Ekonomi, Manajemen, Bisnis dan Akuntansi, 1(4), 344-354.

Prabowo, Y. (2009). Analisis Risiko dan Pengembalian Hasil pada Perbankan Syariah: Aplikasi Metode VaR dan RAROC pada Bank Syariah Mandiri (Risk Analysis and Returns on Sharia Banking: Application of VaR and RAROC Methods at Bank of Sharia Mandiri). Jurnal Fakultas Hukum UII, 3(1), 90-105.

Rivai, V., \& Usman, A. N. (2012). Islamic Economics \& Finance: Ekonomi dan Keuangan Islam Bukan Alternatif, tetapi Solusi (Islamic Economcs \& Finance: Islamic Economics and Finance is not Alternative but It is a Solution). Jakarta: PT. Gramedia Pustaka Utama.

Sally, I. (2015). Pengaruh Good Corporate Governance Terhadap Hubungan Profitabilitas dan Manajemen Laba Dengan Nilai Perusahaan: Studi Empiris Pada Perusahaan Go Public yang Terdaftar di CGPI tahun 2009-2012 (The Effect of Good Corporate Governance on the Relationship between Profitability and Profit Management and Firm Value: An Empirical Study of Go Public Companies Registered in CGPI 20092012). Jurnal Akuntansi, 3(1), 1-28. 
Sanusi, M., \& Zulaikha, S. (2019). The Impact of Bank-specific and Macroeconomic Variables on Profitability of Islamic Rural Bank in Indonesia. Jurnal Ilmiah Ekonomi Islam, 5(03), 317-325.

Siswanti, I. (2016). Implementasi Good Corporate Governance Pada Kinerja Bank Syariah (Implementation of Good Corporate Governance in Islamic Bank Performance). Jurnal Akuntansi Multiparadigma, 7(2), 307-321.

Sobita, N.E, \& Supatra, W. (2014). Pertumbuhan ekonomi dan penyerapan tenaga kerja di Provinsi Lampung. Jurnal Ekonomi Pembangunan, 3(2), 141-166.

Soemitra, A. (2009). Bank dan Lembaga Keuangan Syariah (Islamic Bank and Financial Institution). Jakarta: Kencana.

Sulistianingrum, D. R. (2013). Analisis Pengaruh Financing to Deposit Ratio (FDR), Dana Pihak Ketiga (DPK), Sertifikat Bank Indonesia Syariah (SBIS), dan Non Performing Financing (NPF) Terhadap Return on Asset (ROA) Periode Januari 2009-Desember 2012 (Analysis of the Effect of Financing to Deposit Ratio (FDR), Third Party Funds (DPK), Bank Indonesia Syariah Certificates (SBIS), and Non Performing Financing (NPF) on Return on Assets (ROA) for the January 2009-December 2012 Period). (Unpublished Thesis). Universitas Islam Negeri Syarif Hidayatullah, Jakarta.

Sumarsono, S. (2014). Pengaruh Good Corporate Governance Terhadap Kinerja Keuangan Pada Perusahaan Perbankan yang Terdaftar di Bursa Efek Indonesia 2010-2012 (The Effect of Good Corporate Governance on Financial Performance in Banking Companies Listed on the Indonesia Stock Exchange 2010-2012). (Unpublished Thesis). Universitas Muhammadiyah Surakarta.

Sunarwan, E. (2015). Pengaruh Good Corporate Governance (GCG) Terhadap Kinerja Keuangan Perbankan Syariah: Studi Kasus Pada Bank Umum Syariah dan Unit Usaha Syariah periode 2010-2013 (The Effect of Good Corporate Governance (GCG) on Islamic Banking Financial Performance: A Case Study on Islamic Commercial Banks and Islamic Business Units 2010-2013). (Unpublished Thesis). Universitas Islam Negeri Syarif Hidayatullah, Jakarta.

Suryani, S. (2012). Sistem Perbankan Islam di Indonesia: Sejarah dan Prospek Pengembangan (Islamic Banking System in Indonesia: History and Development Prospects). Muqtasid: Jurnal Ekonomi dan Perbankan Syariah, 3(1), 111-131.

Syam, D., \& Najda, T. (2012). Analisis Kualitas Penerapan Good Corporate Governance pada Bank Umum Syariah di Indonesia serta Pengaruhnya Terhadap Tingkat Pengembalian dan Risiko Pembiayaan (Analysis of the Quality of the Implementation of Good Corporate Governance in Islamic Commercial Banks in Indonesia and its Effect on the Rate of Return and Risk of Financing). Jurnal Reviu Akuntansi dan Keuangan, 2(1), 195-206.

Tumewu, R. C., \& Alexander, S. (2014). Pengaruh Penerapan Good Corporate Governance Terhadap Profitabilitas Pada Perusahaan Perbankan yang Terdaftar di BEI Periode 2009-2013 (The Effect of the Implementation of Good Corporate Governance on Profitability in Banking Companies Listed on the IDX for the 2009-2013 Period). Jurnal Accountability, 3(1), 77-85. 
Veno, A., \& Syamsudin, S. (2016). Analisis Trend Kinerja Keuangan Perbankan Syariah Tahun 2015-2017 (Analysis of Islamic Banking Financial Performance Trends in 20152017). BISNIS: Jurnal Bisnis dan Manajemen Islam, 4(1), 21-34.

Yaya, R., Martawireja, A. E., \& Abdurahim, A. (2016). Akuntansi Perbankan Syariah: Teori dan Praktik Kontemporer (Accounting for Islamic Banking: Theory and Contemporary Practice). Jakarta: Salemba Empat.

Yuliany, L. (2014). Pengaruh Financing to Deposit Ratio (FDR) dan Non Performing Financing (NPF) Terhadap Profitabilitas Bank Umum Syariah: Studi Empiris Pada Bank Umum Syariah yang Terdaftar di Bank Indonesia Periode 2008-2012 (The Effect of Financing to Deposit Ratio (FDR) and Non Performing Financing (NPF) on the Profitability of Islamic Commercial Banks: An Empirical Study of Islamic Commercial Banks Registered at Bank Indonesia Period 2008-2012). (Unpublished Thesis). Universitas Widyatama, Bandung.

Zaman, S., \& Chowdhury, M. M. (2019). Effect of Non-performing Investment on Islamic Banks Performance: An Empirical Study on Islamic Banks in Bangladesh. International Journal of Islamic Business and Economics (IJIBEC), 3(1), 1-11. 